Proc. Estonian Acad. Sci. Geol., 1999, 48, 1, 3-14

\title{
APPARENT EXTENSIONAL STRUCTURES DUE TO VOLUME LOSS
}

\author{
Paul D. BONS
}

Department of Earth Sciences, Monash University, Clayton (Melbourne), VIC 3168 Australia; paul@earth.monash.edu.au

Received 30 June 1998

\begin{abstract}
Extensional structures, such as boudins, extensional faults, and shear bands, are often used to infer a general tectonic extension. However, observations on stromatic migmatites and theoretical considerations, both presented here, show that volume loss can also cause apparent extensional structures, even when the overall deformation is shortening. Extensional structures form in a layer when adjacent layers extend faster, or contract slower than the layer itself. The latter can be due to volume loss in that layer. The relative rates of layer-parallel shortening or stretching determine what structures form, not only the overall applied tectonic deformation. Stromatic migmatites often show layer-parallel extensional structures, which can be explained by the volume loss due to melt extraction. Volume loss due to diagenetic compaction and pressure solution can give rise to apparent extensional structures in sedimentary basins, while it is speculated that on an even larger scale, volume loss in the lower crust due to melt extraction can cause the formation of crustal-scale apparent extensional structures.
\end{abstract}

Key words: deformation, boudinage, extension, partial melting, migmatite, volume loss.

\section{INTRODUCTION}

The tectonic history of geological terrains is largely reconstructed on the basis of structures that are observed in rocks. Such structures are, for instance, cleavages, folds, and faults that indicate the episodes of deformation and the directions of shortening or extension during those episodes. It is clear that we must well understand how these structures form and what they mean if we want to draw correct conclusions on a tectonic history.

Boudinage structures are classical indicators of layer-parallel extension (Lohest, 1909; Cloos, 1947; Rast, 1956; Platt \& Vissers, 1980; Ramsay \& Huber, 1983; Malavieille \& Lacassin, 1988). These structures usually form in layers that are more competent, i.e. stronger, than the adjacent rock and are harder therefore to stretch than the adjacent material. Layer-parallel stretching of the rock then 
leads to necking and sometimes breaking of the competent layers. The result, in outcrop profile, looks like a string of elongate blocks or sausages ("boudins" in French). This process, boudinage, is well understood, and mathematically and experimentally modelled (Strömgård, 1973; Smith, 1975; Lloyd et al., 1982; Neurath \& Smith, 1982; Hildebrand-Mittlefehldt, 1983; Mandal \& Karmakar, 1989; Mandal \& Khan, 1991).

Boudinage is also frequently observed in stromatic migmatites (van der Molen, 1985; Brown, 1994; Brown \& Rushmer, 1997). Here, a layering is formed by, usually strong, parallel alignment of leucosomes. This stromatic layering is generally parallel to remnant bedding in metasediments. Boudinage is often observed in the more fertile layers, i.e. the ones that melted the most (Fig. 1). The observation that most stromatic migmatites show these layerparallel extensional structures would suggest that they generally form in a tectonic environment with layer-parallel extension. However, as van der Molen (1985) already stressed, this inference is based on the assumption of a constant volume of the boudinage system. In this paper I reconsider that assumption, and I will show that volume loss can cause the formation of apparent extensional structures, such as boudins. Such structures can theoretically even form in a tectonic setting of layer-parallel shortening. I use stromatic migmatites, where volume loss is caused by melt extraction, as an example. I will also show that the recognition of the role of volume loss in the formation of apparent extensional structures may be important in other tectonic settings as well, such as sedimentary basins where diagenetic volume loss can occur (Cartwright, 1997) and orogenic belts where granite ascent causes volume loss in the lower crust.

\section{EXTENSIONAL STRUCTURES IN THE FLETCHER CREEK MIGMATITES}

Extensive partial melt structures can be found in the Halls Creek Orogen of northern West Australia (Blake \& Hoatson, 1993). These include amphibolites with trondhjemitic veins as well as stromatic migmatites that are extensively exposed in the rocky bed of Fletcher Creek in the Kimberley region of northern West Australia. These migmatites formed in alternating pelitic and psammitic metasediments of the Palaeoproterozoic Tickalara Metamorphic Suite that in turn alternate with amphibole- and pyroxene-bearing granulites on the 10-100 m scale. Pressure and temperature at time of migmatization are inferred to be about 5-7 kbar and $850 \pm 50{ }^{\circ} \mathrm{C}$ (Oliver \& Barr, 1997). The migmatite and granulite units are folded in open upright folds, with the sedimentary layering quite well preserved in the migmatites. However, some small-scale intra-layer isoclinal folds in the migmatites suggest quite strong deformation with a dominant layerparallel simple shear component. This shearing could have transposed all fabric elements (bedding, stromatic layering) to parallelism. 


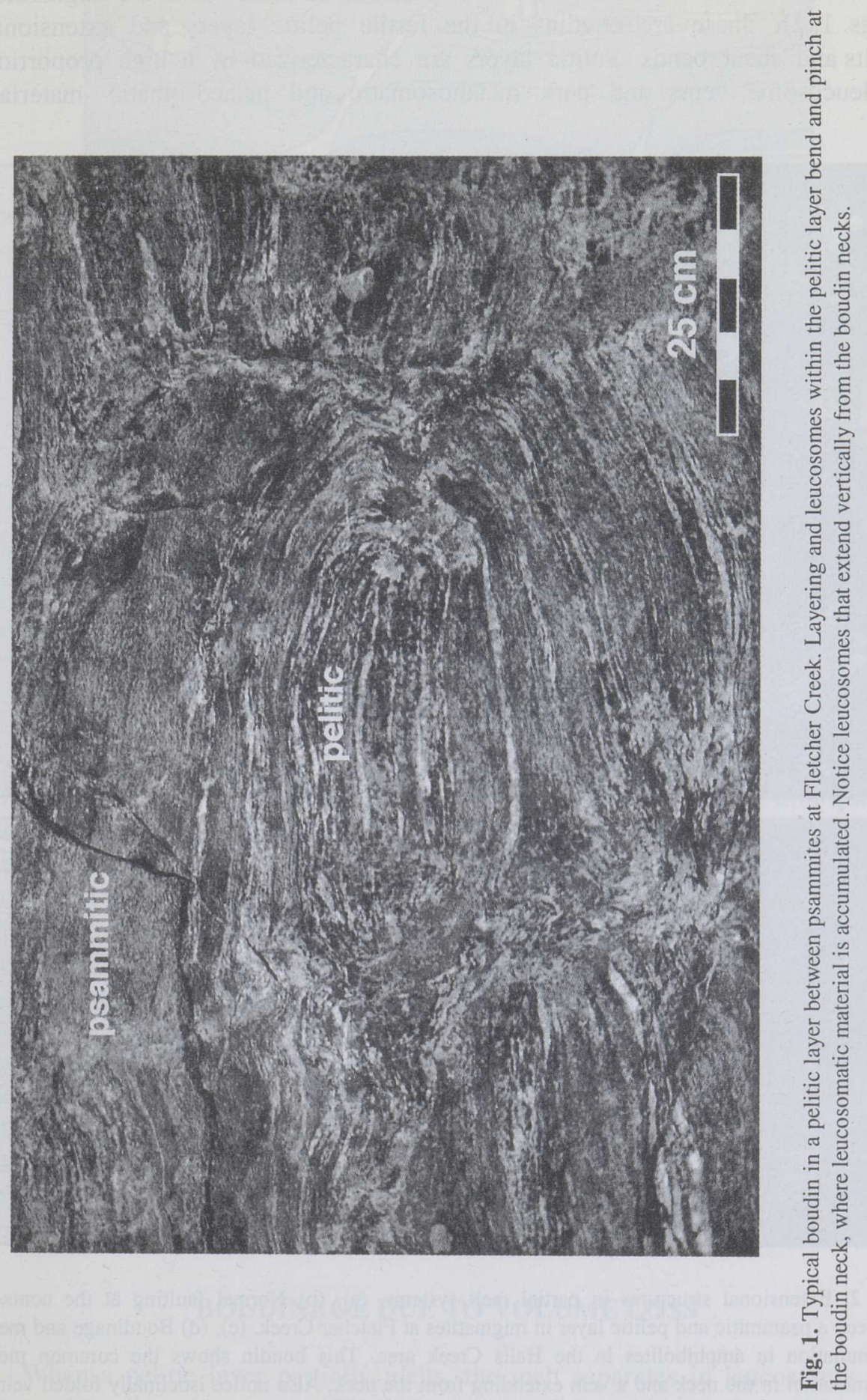


Abundant classical extensional structures can be observed in the migmatites (Figs. 1,2). These are boudins in the fertile pelitic layers and extensional faults and shear bands. Pelitic layers are characterized by a high proportion of leucosome veins and dark melanosomatic and palaeosomatic material.
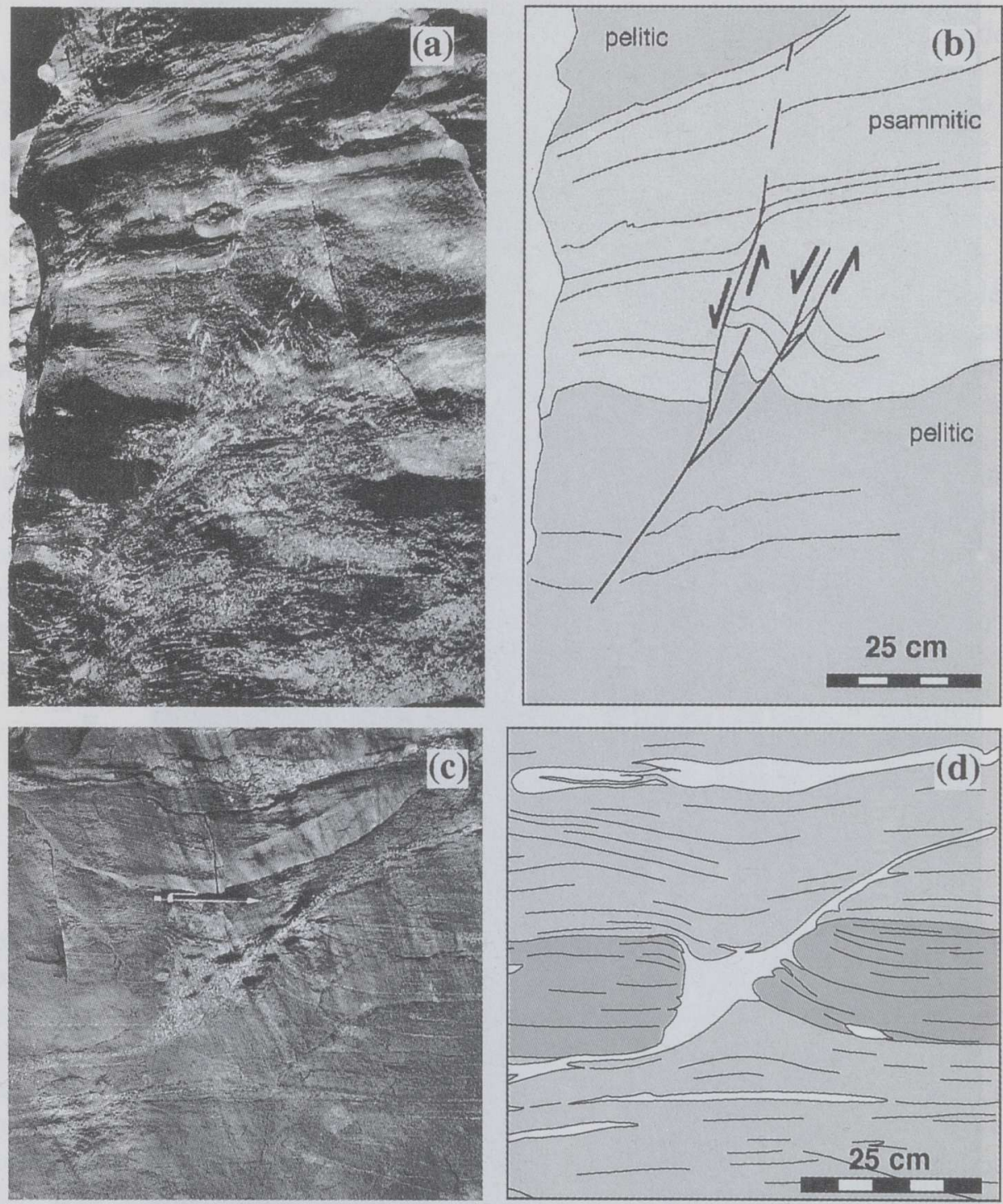

Fig. 2. Extensional structures in partial melt systems. (a), (b) Normal faulting at the contact between a psammitic and pelitic layer in migmatites at Fletcher Creek. (c), (d) Boudinage and melt accumulation in amphibolites in the Halls Creek area. This boudin shows the common melt accumulation in the neck and a vein extending from the neck. Also notice isoclinally folded veins parallel to layering. 


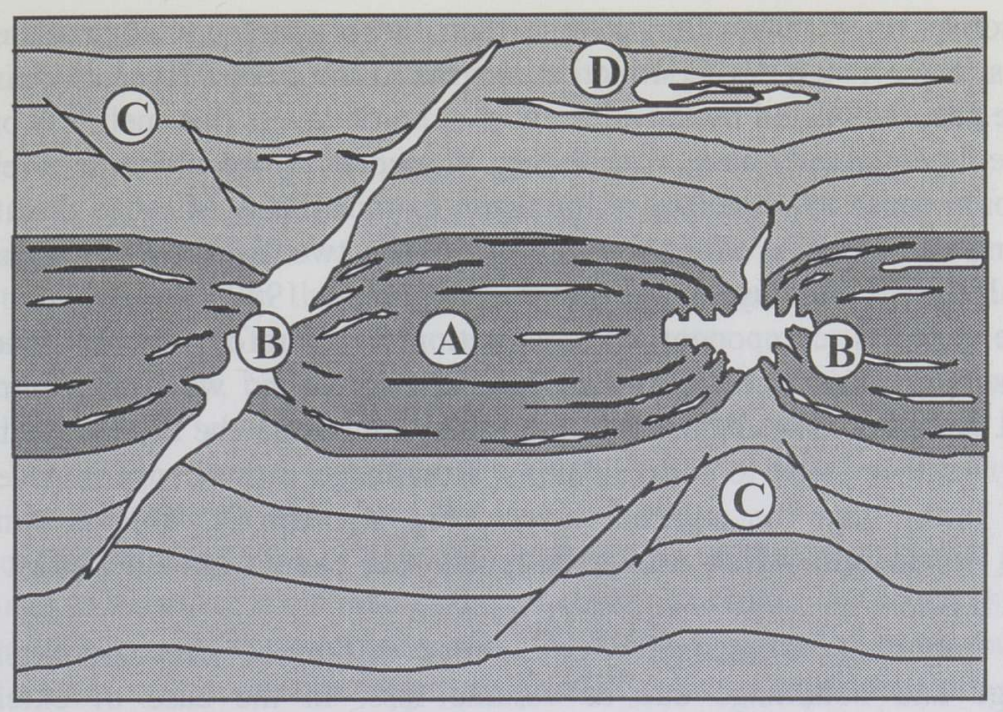

Fig. 3. Typical structures in and around a fertile layer in a partially molten rock, as at Fletcher Creek. A, boudinaged fertile layer (pelite) with layer-parallel leucosomes; B, boudin necks with leucosome pods, often with veins emanating from the neck; C, extensional structures, such as extensional shears, in less fertile layers (psammites); D, evidence for intense shearing, such as (rootless) isoclinal folds.

Psammitic layers are lighter in colour and contain fewer leucosomes. Boudins often show pinching at the ends and the necks are generally filled with quartzrich leucosomatic material (Fig. 1). These are interpreted as remnants of melt that pooled in these necks. Extensional faults and shear bands are common in both pelitic, but especially in the psammitic layers (Fig. 2a,b). Most of these faults and shears contain leucosomatic veins. Often they emanate from boudin necks (Fig. 2c,d), suggesting that they are genetically linked. Apart from layerparallel extension structures, there is evidence for simple shearing (Fig. 2c,d). A schematic summary of these structures is shown in Fig. 3. Although it cannot be determined with certainty, it is most likely that the current leucosomes do not represent all melt that was produced. On the small scale one can see melt that has migrated into large veins and dykes and one can assume that some melt, if not most melt, escaped. Hence, these migmatites and in particular the fertile pelitic layers saw a certain amount of volume loss by extraction of melt.

\section{BOUDINAGE DUE TO VOLUME LOSS}

When a pelitic layer partially melts, the melt separates in leucosomes and a part or all moves away. The remaining solid residue, palaeosomes and 
melanosomes, is of a smaller volume than the original unmelted material: it contracts (Fig. 4, step A). Contraction normal to the pelitic layer, thinning, can easily be accommodated by the adjacent psammitic layers that melt less or not at all: these layers simply have to shift (Fig. 4, step B). Contraction parallel to the layer would cause a shortening of the layer. Compatibility of strain dictates that shortening or stretching along a contact between two layers must be the same in both layers if the layers are coupled (Treagus, 1988; Weijermars, 1992). The layer-parallel component of contraction is therefore more difficult to accommodate, since the pelitic and psammitic layers want to contract by different amounts. The differences in contraction cause the fastest contracting layer to break or neck to form boudins. Boudinage thus occurs in layers that contract faster than the adjacent layers (Fig. 4, step C). This is similar to classical boudinage, which occurs in layers that cannot stretch as fast as the adjacent layers.

It is important to recognize one major difference between extensional boudinage and boudinage due to volume loss. In the case of extensional boudinage, the most competent or strong layers form boudins. In the migmatites, the pelitic layers have the highest melt percentage and would therefore be the least competent layers. If the boudinage in these migmatites was due to layer-

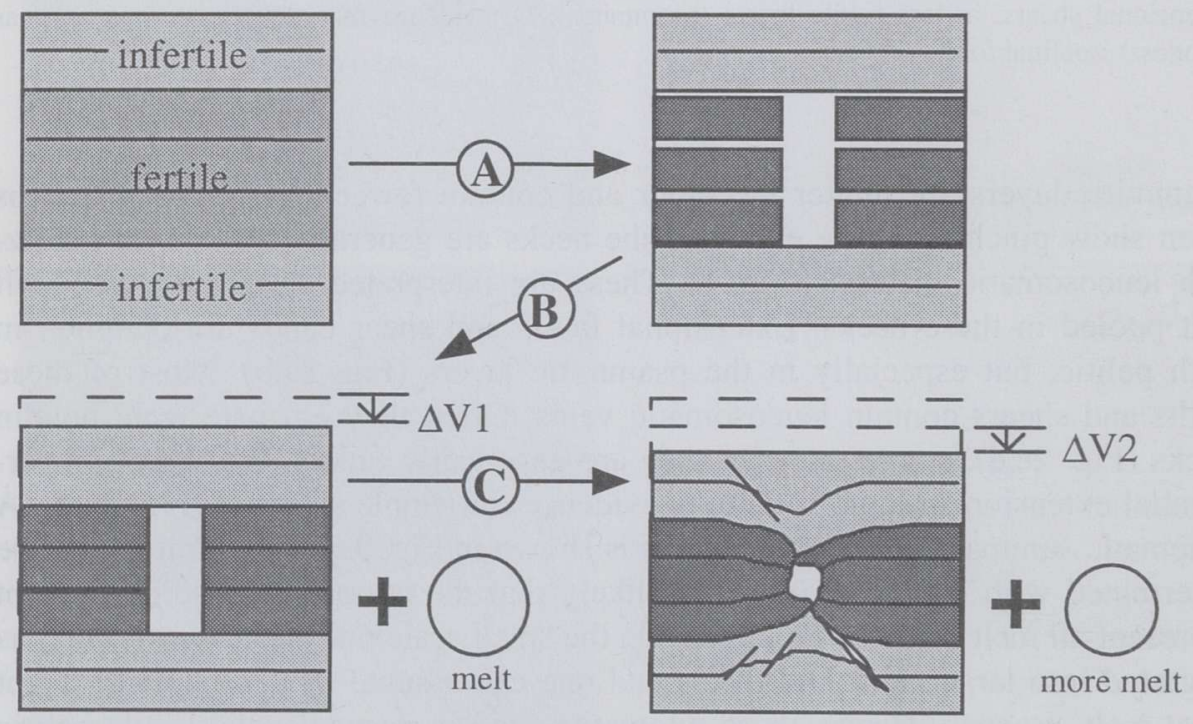

Fig. 4. Schematic sequence of events in the formation of boudins in a fertile layer that melts $30 \%$, forming boudins. Step A: Partial melting of a fertile layer. The solid residue contracts. Step B: Expulsion of melt from layer-parallel melt veins, producing vertical shortening $(\Delta V 1)$. Step $C$ : Further expulsion of melt from non-layer-parallel melt accumulations (boudin necks), accommodated by extension in both fertile and infertile layers, resulting in more vertical shortening $(\triangle \mathrm{V} 2)$. Some melt may remain, especially in the boudin neck and along the escape pathways. Steps A and B are separated for clarity, but would occur simultaneously in nature. Notice that there is no overall horizontal extension needed to achieve the extensional structures. 
parallel extension, the psammitic layers would have formed boudins. In case boudinage is due to volume loss, the layers that lose the most volume form boudins.

It follows that boudinage occurs in layers that cannot maintain the same length as their adjacent layers without breaking or necking. The reasons for this incompatibility can be different: differences in strength of layers during layerparallel stretching or, as in the case of the stromatic migmatites, differences in layer-parallel contraction due to volume loss. The latter case can occur during layer-parallel extension, but also during contraction, as long as the contraction due to volume loss in some layers exceeds the overall applied contraction. In this case the boudinage does not necessarily imply that the boudinaged layer is stronger than the adjacent layers.

The next point to address is how the volume loss in the most fertile pelitic layers causes extensional structures in the adjacent psammitic layers that saw no or little volume loss due to melt extraction. Melt initially pooled in the boudinnecks before extraction. At this stage, the partially molten layer as a whole did not experience volume loss, but only internal redistribution of material. Escape of the pooled melt caused collapse of the boudin-necks. The surrounding solid material filled up the freed space by ductile flow or by brittle faulting. To do this, some layers had to stretch, giving rise to extensional accommodation structures in the psammites. In other words, the extension in the psammites compensated the contraction in the pelites. A more rigorous mathematical treatment of the compensating extension in the non-melting layers is given in the appendix.

From the above it follows that the boudins and extensional faults in the migmatites at Fletcher Creek may not tell us much about the overall deformation in the area. Occasional intrafolial isoclinal folds suggest strong deformation, probably in layer-parallel simple shear. Ideally, layers do not stretch nor shorten in layer-parallel simple shear. However, small perturbations usually cause the formation of folds that get sheared to sheath folds (Quinquis et al., 1978; Bons \& Urai, 1996). Such folds are, however, relatively uncommon at Fletcher Creek. This can be explained by the stretching that compensates volume loss, which would suppress amplification of perturbations that is needed to get folding. Extensive layer-parallel simple shearing could therefore have occurred at Fletcher Creek. However, the fact that melt veins and faults at high angles to the layering are preserved, suggests that the simple shearing ceased towards the end of the melt-production episode. Late structures are then mostly the result of accommodation of volume loss due to melt extraction.

\section{CONCLUSIONS AND IMPLICATIONS}

I have shown that boudinage and associated extensional structures can form when layers stretch or shorten by different amounts. The differences can arise 
from differences in mechanical properties or differences in volume loss, for instance, due to variations in melt production and extraction. Extreme care should therefore be taken when interpreting these structures in terms of the larger-scale deformational setting. Apparent layer-parallel extension can even occur in a setting of overall layer-parallel shortening when the volume loss in some layers exceeds the applied tectonic shortening.

It is clear that the above applies to any case where volume loss is significant. One obvious geological setting where volume loss can be significant is a sedimentary basin. Dewatering is an important compaction and hence volumeloss mechanism in early diagenesis, while at deeper levels pressure solution may remove significant fractions of material in mudstones, shales, and particularly carbonates (Ramsay \& Wood, 1973; Hortenbach, 1977; Beutner \& Charles, 1985; Gray, 1997). The amount of volume loss depends on many factors, one of which is lithology. Carbonates may easily lose tens of percents of their volume due to dissolution. Differences in volume loss between different lithological units can lead to apparent extensional structures on the basin scale, such as layerbound normal fault systems as described by Cartwright (1997).

It is perhaps interesting to speculate what the effect of large-scale mass transfer on the crustal scale would be. For instance, the currently exposed surface of the $700 \mathrm{~km}$ wide Palaeozoic Lachlan Fold Belt in southeastern Australia is covered by up to $50 \%$ of granites (Chappell et al., 1988; Gray \& Foster, 1997). The presence of these granites implies significant volume loss at deeper crustal levels. One can imagine that such large-scale volume loss would produce extensional structures on the 1-10 km scale in the lower crust.

\section{ACKNOWLEDGEMENTS}

I would like to thank Alvar Soesoo for his help in the field and company during the long drive to Fletcher Creek, and for the Estonian and Russian translations. Nick Oliver is thanked for introducing me to the outcrops at Fletcher Creek. Financial support through a Monash University Logan Research Fellowship is gratefully acknowledged.

\section{REFERENCES}

Beutner, E. C. \& Charles, E. G. 1985. Large volume loss during cleavage formation, Habburg sequence, Pennsylvania. Geology, 13, 803-805.

Blake, D. H. \& Hoatson, D. M. 1993. Granite, gabbro, and migmatite field relationships in the Proterozoic Lamboo Complex of the East Kimberley region, Western Australia. AGSO J. Austral. Geol. Geoph., 14, 319-330.

Bons, P. D. \& Urai, J. L. 1996. An apparatus to experimentally model the dynamics of ductile shear zones. Tectonophysics, 256, 145-164. 
Brown, M. 1994. The generation, segregation, ascent and emplacement of granite magma: the migmatite-to-crustally-derived granite connection in thickened orogens. Earth Sci. Rev., 36, 83-130.

Brown, M. \& Rushmer, T. 1997. The role of deformation in the movement of granitic melt: views from the laboratory and the field. In Deformation-Enhanced Fluid Transport in the Earth's Crust and Mantle (Holness, M. B., ed.), pp. 110-143. Chapman \& Hall, London.

Cartwright, J. A. 1997. Polygonal extensional fault systems: a new class of structure formed during the early compaction of shales. In Fluid Flow and Transport in Rocks - Mechanisms and Effects (Jamtveit, B. \& Yardley, B. W. D., eds.), pp. 35-56. Chapman \& Hall, London.

Chappell, B. W., White, A. J. \& Hine, R. 1988. Granite provinces and basement terraines in the Lachlan fold belt, southeastern Australia. Austral. J. Earth. Sci., 35, 505-521.

Cloos, E. 1947. Boudinage. Trans. Am. Geoph. Union, 28, 626-632.

Gray, D. R. 1997. Volume loss and slaty cleavage development. In Evolution of Geological Structures in Micro- to Macro-Scales (Sengupta, S., ed.), pp. 273-291. Chapman \& Hall, London.

Gray, D. R. \& Foster, D. A. 1997. Orogenic concepts - application and definition: Lachlan Fold Belt, Eastern Australia. Am. J. Sci., 297, 859-891.

Hildebrand-Mittlefehldt, N. 1983. Strain fields in and around boudins in a clay experiment. J. Struct. Geol., 5, 465-470.

Hortenbach, R. 1977. Pressure solution processes in carbonates and their importance. Z. Geol. Wissensch., 5, 617-621.

Lloyd, G. E., Ferguson, C. C. \& Reading, K. 1982. A stress-transfer model for the development of extension fracture boudinage. J. Struct. Geol., 4, 355-372.

Lohest, M. 1909. De l'origine des veines et des géodes des terraines primaires de Belgique. Soc. Géol. Belg. Ann., 36B, 275-282.

Malavieille, J. \& Lacassin, R. 1988. "Bone-shaped" boudins in progressive shearing. J. Struct. Geol., 10, 335-345.

Mandal, N. \& Karmakar, S. 1989. Boudinage in homogeneous foliated rocks. Tectonophysics, 170, 151-158.

Mandal, N. \& Khan, D. 1991. Rotation, offset and separation of oblique-fracture (rhombic) boudins: theory and experiments under layer-normal compression. J. Struct. Geol., 13, 349-356.

Neurath, C. \& Smith, R. B. 1982. The effect of material properties on growth rates of folding and boudinage: experiments with wax models. J. Struct. Geol., 4, 215-229.

Oliver, N. H. S. \& Barr, T. D. 1997. The geometry and evolution of magma pathways through migmatite of the Halls Creek Orogen, western Australia. Min. Mag., 61, 3-14.

Platt, J. P. \& Vissers, R. L. M. 1980. Extensional structures in anisotropic rocks. J. Struct. Geol., 2, $397-410$.

Quinquis, H., Audren, C., Brun, J. P. \& Cobbold, P. R. 1978. Intense progressive shear in the Île de Groix blueschists and compatibility with subduction or obduction. Nature, 273, 43-45.

Ramsay, J. G. \& Huber, M. I. 1983. The Techniques of Modern Structural Geology. Academic Press, London.

Ramsay, J. G. \& Wood, D. S. 1973. The geometric effects of volume change during deformation processes. Tectonophysics, 16, 263-277.

Rast, N. 1956. The origin and significance of boudinage. Geol. Mag., 93, 401-408.

Smith, R. B. 1975. Unified theory of the onset of folding, boudinage, and mullion structure. Geol. Soc. Am. Bull., 86, 1601-1609.

Strömgård, K.-E. 1973. Stress distribution during formation of boudinage and pressure shadows. Tectonophysics, 16, 215-248.

Treagus, S. H. 1988. Strain refraction in layered systems. J. Struct. Geol., 10, 517-527.

van der Molen, I. 1985. Interlayer material transport during layer-normal shortening. Part II. Boudinage, pinch-and-swell and migmatite at Søndre Strømfjord airport, west Greenland. Tectonophysics, 115, 297-313.

Weijermars, R. 1992. Progressive deformation in anisotropic rocks. J. Struct. Geol., 14, 723-742. 


\section{APPENDIX}

Let us consider a block of material with a horizontal layer of material that experiences volume loss. For simplicity we treat the problem in two dimensions. As boundary condition we first take that the whole block does not stretch or shorten in the horizontal $(x)$ direction. The contracting layer is of material A, occupying a fraction $F$ of the block. The remaining material $\mathrm{B}$ does not change volume. We describe the velocity vector field $\left(v_{(x, y)}\right)$ resulting from the volume loss in layer A and possible layer-parallel simple shear deformation in terms of the velocity gradient tensor $\mathbf{L}$, which is defined by (Passchier, 1987):

$$
\mathbf{L}=\left(\begin{array}{ll}
\partial v_{x} / \partial x & \partial v_{x} / \partial y \\
\partial v_{y} / \partial x & \partial v_{y} / \partial y
\end{array}\right)
$$

A convenient property of the velocity gradient tensor is that $\mathbf{L}_{\text {TOT }}$ for the whole block is the proportional sum of $\mathbf{L}_{\mathrm{A}}$ and $\mathrm{L}_{\mathrm{B}}$ :

$$
\mathbf{L}_{\mathrm{TOT}}=F \cdot \mathbf{L}_{\mathrm{A}}+(1-F) \cdot \mathbf{L}_{\mathrm{B}}
$$

If the volume loss rate in layer $\mathrm{A}$ is $\beta$ and this loss causes an equal contraction in all directions within the layer, then (taking stretching as positive)

$$
\mathbf{L}_{\mathrm{A}}=\left(\begin{array}{cc}
-\beta / 2 & \gamma_{\mathrm{A}} \\
0 & -\beta / 2
\end{array}\right) .
$$

Here, $\gamma$ is the shear strain rate for horizontal simple shear, which does not violate the condition of no horizontal change in length of the whole block. The velocity gradient for the whole block can also be constructed:

$$
\mathbf{L}_{\mathrm{TOT}}=\left(\begin{array}{cc}
0 & \gamma_{\text {TOT }} \\
0 & -\beta
\end{array}\right)
$$

We can now combine Eqs. (2)-(4) to determine what the average velocity gradient is in material $\mathrm{B}$. This gives us

$$
\mathbf{L}_{\mathrm{B}}=\left(\begin{array}{cc}
\frac{F \cdot \beta}{2(1-F)} & \gamma_{\mathrm{B}} \\
0 & \frac{-F \cdot \beta}{2(1-F)}
\end{array}\right)
$$

The volume conservative material $\mathrm{B}$ experiences, on average, horizontal extension to compensate for the volume loss of layer A. At the same time, the material can experience simple shearing parallel to the layering, which is not affected by the volume loss. If the boundary condition of no horizontal change in 
length is relaxed, material B is still, on average, in horizontal extension, as long as the overall horizontal shortening does not exceed $F \beta / 2(1-F)$.

\title{
Additional reference
}

Passchier, C. W. 1987. Efficient use of the velocity gradient tensor in flow modelling. Tectonophysics, 136, 159-163.

\section{KIVIMI MAHUKAO PÕHJUSTATUD NÄILISED TÕMBESTRUKTUURID}

\author{
Paul D. BONS
}

Tõmbestruktuurid, nagu budinid (tektoonilised läätsed) ning tõmbe- ja nihkemurrangud, on tihti kasutatavad regionaalsete tektooniliste tõmbejõudude tunnuselementidena. Töös tutvustatud stromaatiliste migmatiitide uuringud ja teoreetilised käsitlused on näidanud, et mahukadu maakoores võib põhjustada näiliste tõmbestruktuuride tekke, seda isegi juhul, kui regionaalne tektooniline keskkond on kompressiooniline. Tõmbestruktuurid moodustuvad kivimikihis, kui ümbritsevad kihid liiguvad kas aeglaselt või kiiremini. Viimane väljendubki kivimimaterjali kaona (võrrelduna ümbritsevate kihtidega). Kivimikihiga paralleelse kompressiooni ja tõmbe omavaheline suhe määrab moodustuvate struktuuride iseloomu, seega ei tee seda mitte ainult üldine tektooniline deformatsioon. Stromaatilistes migmatiitides on tihti näha kihtparalleelseid tõmbestruktuure, mida võib seletada kivimimaterjali kaoga kivimi sulamisel. Geoloogilise materjali kadu diageneetiliste protsesside ja mineraalide rõhust tingitud lahustumise tagajärjel võib põhjustada tõmbestruktuuride tekke settekivimite basseinides. Kivimimaterjali sulamisest põhjustatud mahukadu maakoore alaosas võib esile kutsuda tõmbestruktuuride (settebasseinide) moodustumise maakoore ülaosas.

\section{СТРУКТУРЫ РАСТЯЖЕНИЯ ПРИ ПОТЕРЕ ОБЪЕМА}

\author{
Пауль Д. БОНС
}

По структурам растяжения, таким как будины, сдвиги и сбросы, часто определяется распространение того или иного тектонического режима. Приведенные в статье данные исследования строматических мигматитов и теоретические разработки показывают, однако, что потеря объема может 
вызвать появление видимых разломов даже тогда, когда происходит сжатие. Структуры растяжения в слое образуются в том случае, если соседние слои растягиваются быстрее или, наоборот, сжимаются медленнее, чем сам слой. Эти структуры в строматических мигматитах вытянуты в параллельном слоям направлении, что может быть объяснено потерей объема при плавлении пород и интрузивной деятельности. Потеря объема при диагенетическом уплотнении вызывает появление структур растяжения в осадочных бассейнах, тогда как потери в масштабе нижних слоев земной толщи могут привести к образованию структур растяжения (осадочных бассейнов) в верхней части земной коры. 